\title{
The Woman with the Alabaster Jar: The Forgiven Sinner
}

\author{
Linda Elaine Vogt Turner
}

Faculty of Arts and Social Sciences, Simon Fraser University, Canada

Copyright $(\mathcal{C} 2015$ by authors, all rights reserved. Authors agree that this article remains permanently open access under the terms of the Creative Commons Attribution License 4.0 International License

\begin{abstract}
This article lifts up the Woman with the Alabaster Jar of Luke's Gospel, chapter 7. The Pharisee saw her as a sinner because according to Pharisaic laws she was. Jesus, the Teacher at the Pharisee's house agrees. He says the Woman has sinned much and is forgiven much. This paper explores the importance of forgiveness and the importance of showing hospitality, love, and justice to one's neighbour. Roman Catholic tradition used to conflate this woman with Mary Magdalene claiming that Mary Magdalene was the sinner forgiven for her great love for the Teacher. In recent years, many people have opposed Roman Catholic tradition because too many Christians were exploiting the image of Mary Magdalene in a negative way to gain power over women and people of other races and faiths. [1] Thus this article opposes both the modern and the old exploited views. It maintains that the Woman of Luke 7 is the bitterly treated woman of the Gospel who overcame and rose with the Teacher as the Christ. She earned the title "Mary" because of the way people bitterly treated her for "breaking" God's ancient Patriarchal law that scholars and priests were using to chastise and exclude women and their Gentile and Samaritan neighbours from the great banquet of life where God's Love and eco-justice is for all. She earned the title the "Magdalene" because she is a tower of strength and a great light, a burning torch that the Teacher speaks face to face with in the garden.
\end{abstract}

Keywords Patriarchal Laws, Forgiveness, God's Love, Eco-justice

\section{Introduction}

This article lifts up the Woman with the Alabaster Jar. Prior to 1969, Roman Catholic tradition claimed that this woman was Mary Magdalene. [2] In fact, in 1910 the Roman Catholic scholar, Hugh Pope maintained that conflating Mary Magdalene with the anointing stories is fundamental to understanding the Christian teaching of forgiveness.[3] In 1969 Roman Catholicism officially conformed to the Eastern Orthodox and Protestant view that Mary Magdalene should not be confused with Mary of Bethany or the sinner of Luke
7.[4] In 2011, the author of this article successfully asserted and defended Hugh Pope's position for a master's thesis project at Simon Fraser University. [1] Like Margaret Starbird [5] and Dan Brown, [6] this thesis project examined the claim that Jesus was married. However it concluded Martha, rather than Mary Magdalene was most likely the housewife married to Jesus. [1] Thus it further asserted the Magdalene was the forgiven sinner of Luke 7 and the Woman of Bethany and also the Woman Caught in Adultery, who the Teacher called Mary, [7] knowing she was weeping bitterly and looking for her Lord . [1, 8] This thesis project [1] also examined the various legends and art that depict Mary Magdalene as having red hair. Although oral tradition depicts Mary Magdalene as being a rufus, ${ }^{1}$ a lady in red, [ 1] scripture does not explicitly mention her hair colour. Scripture does however depict Simon as being the father of Rufus. [9] Scripture also asserts Rufus as being someone chosen by the Lord [10] and mentions an elect lady, a chosen lady, and a chosen sister. [11]

The idea of Mary Magdalene being a spirited red head persists in popular culture despite scant explicit biblical evidence. Disney movies such as The Little Mermaid,[12] and Brave [13] are evidence of this. Popular culture and some theologians [14-16] are resisting modern theological trends to revision Mary Magdalene as merely a faithful disciple. In doing so, some revisionists separate her from Mary of Bethany, the Woman forgiven for her sins in Luke 7, and any theology that suggests she has always been known as the scarlet sinner. [2,17-19] Therefore, this article resists those revisionists and reexamines theological assumptions concerning sin and forgiveness in the context of Red and Simon, the Pharisee [the spiritual father], [20] who hosted the banquet where the anointing in Luke 7 took place. [21]

In preparation of this reexamination, this article asks readers to take a moment and recall The Garden of Eden Story. The four main characters are: God, the Serpent, Eve and Adam. How does sin destroy this fourfold relationship? The Fall starts with the question posed by the Serpent. Did

\footnotetext{
${ }^{1}$ Rufus is a proper masculine noun meaning red. See Blue Letter Bible. "Dictionary and Word Search for Rhouphos (Strong's 4504)". Blue Letter Bible. 1996-2010. 14 Sept. 2010.

$<$ http://www.blueletterbible.org/lang/lexicon/lexicon.cfm?

Strongs $=\mathrm{G} 4504 \& \mathrm{t}=\mathrm{KJV}$
} 
God really say you couldn't eat of every tree in the garden? [22] Or does it? Is the Serpent the one at fault here?

\section{The Garden of Eden Story}

\subsection{The Blame Game}

In The Garden of Eden Story, Eve and Adam also questioned the dietary restrictions imposed upon them. They both ate from the forbidden tree, the tree of good and evil. Then "the man and his wife hid themselves from the presence of the LORD God among the trees." [22] Then when the LORD God called out to them, Eve blamed the Serpent, Adam blamed Eve and when the LORD GOD spoke to the Serpent, the Serpent did not say a word. As a result, God expelled Adam and Eve from the Garden and put a bitter curse on the Serpent. God made the Serpent eat dust and to become a bitter enemy of Eve and all her descendants [23]. During the Ecumenical Decade of the Churches in Solidarity with Women, Mercy Oduyoye [24] spoke out against this blame game attitude found in scripture. She said, "'Lord, we did it' should be our common confession, not 'the woman you gave me' did it or 'I did it in obedience to my husband." [24] We should remember Oduyoye and her wise words, when our relationships break down and we see poverty and eco-injustice.

\subsection{Life Experience}

My life experience has taught me people care about food and they care about rules and points of order. When I babysit my grandchildren and arguments arise concerning access to food and the restrictions concerning between meal snacks, their relationship starts to break down. They often do like Adam and Eve do. They point the finger of blame away from themselves and try to get me the visiting Grandma to scold, shame, blame and curse the siblings breaking the rule or the one remembering and citing the rules in the first place.

So experienced parents know. Things would have been so different, had Adam and Eve the wisdom, humility and faith to say. "We did it. My smooth snake of a brother is not the only one to blame. We weren't happy with the rules either. So, we freely ate from your forbidden Tree, O God. Forgive us."

Today, many parents are coming to understand that bullies are fast becoming a problem for our school play grounds. Some parents are of the opinion that bullies bully because the victim and those witnessing the bullying say and do nothing to stop the bully. Bullies use and abuse the power given to them by their natural talents and their admirers. Bullies demand compliance and allegiance. They harass, name call, and shame people who may threaten their admiration and their privilege as leader. Often their victim is someone who is different, new or vulnerable in some way. Compliance wins the bully friends, respect and power. More importantly, compliance to the bully's demands allows the bully's supporters to coerce the vulnerable person to conform to social norms.

\section{The Greek Testament Story}

\subsection{The Woman with the Alabaster Jar}

In the Greek Testament story of The Woman with the Alabaster Jar, Simon the Pharisee and the visiting teacher identify the Woman with the jar as someone who is a sinner. This has given rise to theology that has assumed she was bad or immoral. [25] So keeping Oduyoye's wise words in mind, this article reexamines this story asking the question. Who is this who even or also forgives sins?

\subsection{The Forgiven Sinner}

One of the Pharisees asked Jesus to eat with him, and he went into the Pharisee's house and took his place at the table. And a woman in the city, who was a sinner, having learned that he was eating in the Pharisee's house, brought an alabaster jar of ointment. She stood behind him at his feet, weeping, and began to bathe his feet with her tears and to dry them with her hair. Then she continued kissing his feet and anointing them with the ointment. Now when the Pharisee who had invited him saw it, he said to himself, "If this man were a prophet, he would have known who and what kind of woman this is who is touching him-that she is a sinner." Jesus spoke up and said to him, "Simon, I have something to say to you." "Teacher," he replied, "speak." "A certain creditor had two debtors; one owed five hundred denarii, and the other fifty. When they could not pay, he canceled the debts for both of them. Now which of them will love him more?" Simon answered, "I suppose the one for whom he canceled the greater debt." And Jesus said to him, "You have judged rightly." Then turning toward the woman, he said to Simon, "Do you see this woman? I entered your house; you gave me no water for my feet, but she has bathed my feet with her tears and dried them with her hair. You gave me no kiss, but from the time I came in she has not stopped kissing my feet. You did not anoint my head with oil, but she has anointed my feet with ointment. Therefore, I tell you, her sins, which were many, have been forgiven; hence she has shown great love. But the one to whom little is forgiven, loves little." Then he said to her, "Your sins are forgiven." But those who were at the table with him began to say among themselves, "Who is this who even forgives sins?" And he said to the woman, "Your faith has saved you; go in peace." [21]

\subsection{Seven Key Points}

1) Simon is a Pharisee, a spiritual father, one of an elect body of lay elders. Pharisees were progressive lay lawyers, who judged and passed down the oral traditions, including the moral and legal traditions of 
the Fathers [Elders]. [20,26-27 ]

2) The storyteller is the only one who identifies the Teacher as Jesus.

3) Simon's actions speak volumes. He acts like a father or a groom who is unhappy with the chosen woman. He sullies her reputation with unspoken thoughts that the Teacher reads by Simon's demeanor. Simon's unspoken thoughts "what kind of woman this is who is touching him - that she is a sinner" shame and humiliate her.

4) The Woman stands behind the Teacher, bathes his feet with her tears, wipes them with her hair, kisses them, and anoints them with ointment.

5) This is a sensual, intimate tableau full of power and loving emotion that also speaks volumes.

6) In response to the Woman's tears and Simon's reaction the Teacher uses a parable as if he were holding up a mirror to Simon. This reveals Simon as a credible judge and spiritual father who has neglected his role as host to provide hospitality to a guest that the Woman loves.

7) As the drama unfolds, Simon and the bystanders come to a greater understanding. The Woman and the Teacher have sinned and so has Simon. All three have been forgiven much and all three love much.

In the context of the seven key points, the Woman's courageous and powerful tableau can be interpreted in the following way. "Teacher, I have great affection for you. I stand behind you in front of Simon and his other invited guests. I stand here silently, giving you my love and my highest praise. My tears reveal my hurt feelings and my frustration. Simon and others have doubted my integrity and my faith in the messianic prophecy. Your words and Simon's actions judge me foolish, prodigal and sinful for making such a lavish display anointing you so dramatically."

It can also be interpreted in this way. "Simon you are a wise spiritual father, a village elder. I love and adore you. With your keen knowledge of scripture and oral tradition, you are like a skillful gardener who cuts off every branch in the tree of the elders that bears no fruit. [28-29] However, you have hurt me and shamed me in front of the Teacher and his disciples. The teacher whose feet I kiss brought me here so that you and I and he could get better acquainted. Can you not see that the Teacher and I want to honour you as an elder and the father of the messianic prophecy? [11]My kisses and my ointment convey my desire to make peace and heal the schism in our worshipping communities. The Teacher and I have sinned, and I am asking you Simon to forgive us and make room in your heart for us,"[30-31].

\subsection{Simon the Father and Judge}

The Teacher and the Woman give Simon the power of father and judge here. We give Simon the judicial power to bully if we let Simon and the teacher "sully" or blaspheme the Woman as an immoral law breaker to protect the Teacher's name and reputation. Forgiving one another our sins is how we hold our anchor and show our faith in the
Triune God. It is how we as ambassadors of Christ show our trust in the Father when we continually pray and teach others to pray "Our Father in heaven, hallowed be you name...forgive us our debts as we have also forgiven our debtors."[32]. We also show our love, respect and trust for the Teacher when we see him clearly as someone forgiven for loving both Martha and Mary. [33-34]

Christians long familiar with the hymn "Will Your Anchor Hold" sing out the refrain loud and clear following the last seven words of the third verse: "while, our hopes abide within the veil." [35] They trust the love of Jesus that is extravagant and forgives sins. The Woman anointing the Teacher's feet is veiled. Her name is not revealed until Jesus starts to travel from town to town and other people come to realize who this woman with the jar is. In the second verse after Jesus says to the Woman "Your faith has saved you, go in peace, Luke unveils the woman. [36] He names her "Mary, called Magdalene, from whom seven demons had gone out," [37] This is Good News. If we trust in the veiled extravagant love of Jesus, seven demons will go out of us too. Our oppressive thoughts, doubts, fears and emotions-blinding us to the truth-will leave us. We will make peace with ourselves and all our relations. Like the blind man, our eyes will see the truth, we will throw off our cloak, and honour our father, our mother and our teacher [rabbouni] [7, 38] by renewing the whole creation with social ethics that undergirds the theology of women and men. [24, 42]

\subsection{The Great Banquet}

The kingdom of heaven has been compared to a great dinner or a wedding banquet. [39-40] In Luke's gospel, the master is angry because the invited guests are making excuses for not coming to the banquet. So in anger, the master of the banquet instructs the slave in charge of hospitality to compel people to come in so that their house will be filled. Thus the master says, "For I tell you, none of those who were invited will taste my dinner. [39] In Matthew, the host is a king. The king becomes angry when he notices one of his guests not wearing a wedding robe. He calls the man his friend and asks him how he got in without wearing a wedding robe. When his friend remains speechless, the king has him bound hand and foot and thrown into the outer darkness. [40]

This article lifts up the story of the Woman with the Alabaster Jar as an example of how some Christians have used this story to bully or compel people to repent and convert to Christianity. In doing so, they have exploited the tearful woman and her story to foster an idyllic view of Jesus as the one who committed no sin [41] as if the Pharisee and the Woman with her rich jar were bad and the Teacher she loved good. [25] Moreover, by promoting such a view, people have created a negative stereotype of Mary Magdalene and women who love outside biblically established morality. [1-2] Separating Mary Magdalene from the Woman in Luke 7, exacerbates the negative stereotype because it fails to see the significance of the gospel writer 
who made forgiveness the crux of the story to reveal the truth about God's forgiveness.[3]

According to Alexandros Papaderos, [42] "the truth is the foundation of Christian ethics. And this truth reveals to us that God and the Good are identical, since only the Triune God is good." To undergird this theology, Papaderos cites the story of the rich ruler who says to Jesus, 'good teacher what must I do to inherit eternal life.' [43-44]To which the teacher responds. 'Why do you call me good? No one is good but God alone.' [43-44] Then Papaderos [42] adds, "God is the highest good toward which humanity should strive confidently despite its sinfulness and the evil in the world."

Fostering the idyllic view of Jesus' goodness or sinless state without understanding the role of the Trinity and the role that forgiveness plays in Jesus' sinless state has been problematic. The church has sent priests and nuns out into the world without a wedding robe, insisting everyone must wear one. According to Jewish tradition, when a bride and groom get married, they are "purified of past mistakes" and become as "pure as newborn babies." [45] This means that "the family...begins on the day of the wedding. [45] In preparation for the wedding, both the groom and the bride purify themselves.[45] In a zeal to show love for Jesus, one can easily lose sight of Jesus as the forgiven bride, groom and officiating rabbi including the invited friends and family. Margaret Starbird, [5] Dan Brown [6] and Vogt Turner [1] have opened up the discussion of Mary Magdalene and her relationship to Jesus. So now perhaps, more people will re-discover Jesus coming out of the pages of scripture as the forgiven, groom, bride, teacher, beloved spouse and those others committed to living in love with respect for all people and all creation.

Welcoming people into the household of the Triune God in the name of Christ and teaching one another how to be good stewards of creation, we Christians have made many mistakes. We have contributed to racism, colonialism, apartheid in South Africa, the Magdalene laundries in Britain, and the Residential School scandal in Canada. We have also fought against such practices. However in the process, we have cried out to Jesus saying...Good Teacher, and then believing the Good Teacher to be God-we have assigned the label of sinner to-rich persons, prostitutes, unwed mothers, mistresses, gay and lesbian people, indigenous people, people of other faiths and people of mixed heritage. Witnessing to these people and their tears, we should be asking them for our forgiveness and assuring them that their faith has saved them.

Christian teaching asserts the church is Christ's body and through the scripture proves Jesus to be the Christ.[46-47] Further to this teaching, scripture says the church is Christ's reconciled body. [48-49] Every Easter as the drama unfolds, scripture reminds the faithful there were two people named Jesus brought before Pilate. [50] These were: Jesus the Messiah and Jesus Barabbas [the son of the father]. [51] A third name is also mentioned: Jesus of Nazareth whom Pilate named the "King of the Jews." [52] When questioned by Pilate, Jesus of Nazareth said nothing to the charges. [53]
This silence crucifies the body of Jesus. If we like the crowd only see and release one Jesus, Jesus the son of the father, it is because we are looking at Jesus' reflection darkly through a colonial lens. We need to allow the truth as revealed by the Triune God to see the other two Jesus' and let our faith bring us into communion face to face with the crucified and then the resurrected Jesus as a unit. [54-55] If we see Jesus as the forgiver, the only one sinned against, we need to look again. Simon carried the cross for Jesus. [9] So we must not let the many ways people have perceived and described Simon deceive us or obscure our vision. Nor must we allow the Teacher speaking to the rich ruler to deceive us. [43-44] The Teacher is not singularly good. The Teacher is a forgiven sinner like the Woman and Simon, for as Paul writes to the church at Rome, "all have sinned and fall short of the glory of God." [56] And yet, Paul [57] says "God made him [the one] who knew no sin to be sin for us, so that in him [the one] we might become the righteousness of God."

So how can three sinful bodies coming in the name of Jesus: Jesus the Messiah, Jesus Barabbas, and Jesus of Nazareth be this him [ this one] who knew no sin? [57] Firstly, scripture [58] says whoever loves is born of God and knows God. Secondly, it [59 says "No one who is born of God will continue to sin, because God's seed remains in him [them]; he [they] cannot go on sinning, because he [they] has [ve] been born of God." Thirdly, the same Teacher who claims only God is Good, [43] opens Simon's eyes to the truth about forgiveness and love [60] by telling a simple parable that allows Simon to see himself as one who has also sinned much and can therefore also love and forgive much.

At the $6^{\text {th }}$ Assembly of the World Council of Churches, William Lazareth [61] presented Andrei Rublev's icon of the Holy Trinity to remind delegates and visitors God is Love because God is Triune. Thus it is extravagant love to say God is with us and God is a forgiven and a forgiving body who loves much. According to Jurgen Moltmann, [62] "the church is holy in its unity and in all its members, not in itself but in Christ...the sanctified church is always at the same time the sinful church. Through its continual prayer 'forgive us our trespasses,' it recognizes itself as being in sin and at the same time as being holy in the divine forgiveness of sins." Surely there is enough evidence to see Jesus as the indivisible holy incarnation of the Father, the Son and the Spirit clothed in scarlet. This may create a stumbling block for some and seem foolish to others.[63]. For those who have been forgiven much and have much love to show [60], Jesus is their rock, their salvation and their fortified tower. [5,64-65]

\subsection{The Woman, the Teacher and the Father Love Much}

Returning to the story in Luke 7, the Woman, Simon, and the Teacher love much, because all three have been forgiven much. Simon sins too. His sin is the sin of inhospitality. [66] He offends his guest who is a renowned teacher and hurts the feelings of a woman who came to honour both Simon and the Teacher. Simon offers his guest no kiss of peace or foot 
water, and his facial expression and body actions reveal his inward doubts about the prophetic ability of his guest and the faith and integrity of this woman who greets the Teacher with love. Thus the Teacher tells a parable about a man owing a large debt and another owing a smaller debt. Simon's debt may seem like the smaller debt. However, as Simon judicially decides that the one to whom the larger debt is forgiven will love the most, he says to her, "Your sins are forgiven"(Emphasis added). The text in the NRSV translation is unclear. He could be Jesus and this Jesus who forgives could be Simon or the Teacher or both. The people sitting at the table with Simon and Jesus begin to say among themselves. Who is this who even or also forgives sins? Later as the story of Simon, the Teacher and the Woman forgiven for their sins reaches legendary proportions, we see Jesus in three persons standing trial in front of Pilate. [50-52] On Trial in front of Pilate, we see Jesus saying nothing. [53] and this lets Pilate release Jesus the son of the Father and lets the crowd crucify Him with two other people, one on either side and Jesus in between. "Pilate also had a sign lettered and put on the cross. The inscription was: Jesus The Nazarene The King of the Jews." [67] In 2 Corinthians, Paul [68] tell us that we are not to regard Christ from a human point of view, [as a sinner]. We are to think of Christ and anyone who is in Christ, as a new creation, [without sin]. For in Christ, God was reconciling the world to [God's] self, not counting their trespasses against them. If we truly believe this, then the trespasses [sins] of the three human incarnations of the Triune God crucified as Jesus, the Nazarene and the King of the Jews are forgiven.

The Forgiven Woman Story gives us an opportunity to understand the power play at the cross to reverse the Fall and reconcile the household of God, justly and evenly. The question asked by those gathered at the tables of the Teacher and Simon is the crux of this paper, and the key question that Simon and all those compelled to carry the cross of Jesus are compelled to answer. Who is this who even forgives sins?

\subsection{The Way to Peace and Restorative Justice}

We need to see the way to peace and restorative justice as a faithful way. We need to learn how to forgive one another evenly, equitably. Even when someone blames the other or acts like a bully. Even when we are the ones who are playing the poor me look at me I'm the victim card. We need to identify the power struggle that is going on and learn how to share power in an even way. We need to realize that even "forgiveness" is power. Not giving the "other" the power to forgive also is withholding power and setting up the relationship for a mighty big fall or a painful dissolution.

As members of the body of the Risen Christ we are ambassadors of peace and reconciliation. $[48,68]$ This takes time. We are to think of Christ and the household of faith living the Christian story as a new creation. This is the first step. Yet we Christians also need to realize that forgiveness is a creative process. Forgiveness brings peace and reconciliation when all offending and offended parties are able to forgive and begin again building up the body with the Love that the Risen Christ reveals.

\subsection{The Stone Suddenly Gave Way}

After a long two days that probably felt like 25 years to those hovering, waiting and watching, the stone, sealing the tomb in breathless silence and darkness, suddenly gave way. The Woman and the Teacher were reunited "face to face." [69] Prior or in the midst of this reunion, the Woman suffers a major setback. She is acutely aware that she has no husband. She weeps and cannot rejoice. It appears as if she doubts the prophecy has come true. However, she stubbornly clings to the hope, searching for her redeemer, the one who makes good his pledge to restore her sovereignty as his royal bride. $[65,70-72]$ For a moment she considers her own fallibility. She supposes the Teacher may be her promised gardener and king. [29] who has taken her Lord's body. [73] So she proceeds with an assumption.

"Supposing him to be the gardener, she said to him, 'Sir, if you have carried him away, tell me where you have laid him, and I will take him.' Jesus said to her, 'Mary.' She turned and said to him in Hebrew 'Rabbouni!' (which means Teacher). Jesus said to her, 'Do not hold onto me because I have not yet ascended to the Father. But go to my brothers and say to them, 'I am ascending to my Father and your Father, to my God and your God." [74]

\subsection{The Resurrection Sends the Disciples back to Bethany}

With this annunciation, Mary Magdalene's confidence is restored. She is sure. Simon is the Father who has heard her lament and smelled her perfume and is now waiting with outstretched arms to welcome her elect Rabbouni and his beloved with the kiss of peace. [21] Like the Bride in Song of Songs, Mary [75] sees herself coming up from the wilderness (of her tears and doubt), holding onto her beloved. ${ }^{2}$ She goes to the disciples and announces "II have seen the Lord'; and she told them that he had said these things to her." [76] With this realization comes a fuller realization of the resurrection. The Magdalene's reunion with the Rabbouni was just the first step in their ministry of reconciliation. The next step brought the Rabbouni back to Bethany where the ascension took place. [77]

A lot of activity takes place at Bethany. Bethany should remind believers of Martha's worry [78] and her testimony of faith. It was at Bethany where Martha [79] declared, "yes Lord, I believe that you are the Messiah, the Son of God." It is also here in Bethany where the death and resurrection of Lazarus occurs. It is also where Martha speaks to Mary

\footnotetext{
${ }^{2}$ For centuries on Mary Magdalene's feast day, Roman Catholic liturgy included passages from the Song of Solomon [5 ] and Hippolytus saw both Mary and Martha as the Bride who welcomed Jesus as the Messianic Bridegroom outside the tomb in the garden.[1]
} 
privately. "The Teacher is here and is calling for you." [80] Furthermore, six days before the Passover festival, Martha and Mary give a dinner in Bethany and invite Jesus. Both Jesus and Lazarus attend. And here too at this dinner in Bethany with Martha and Lazarus present, Mary anoints Jesus. This time Judas, the son of Simon Iscariot accuses Mary of cheating the poor. Judas thinks she should have sold her ointment and given the money to the poor. [81]

This is a lot to comprehend, especially because the Gospel tells us that Judas is a thief who betrays Jesus to the authorities. [82-83] As the Gospel stories reveal, Satan had entered into the heart of Judas. [84-85] and it is here in Bethany where Jesus says. "Truly I tell you, wherever the good news is proclaimed in the whole world, what she has done will be told in remembrance of her." [86-87]

With faith in that realization, this article goes beyond the Vogt Turner [1] thesis project. This article goes forward in faith believing that the Magdalene is the feminine Jesus who speaks up and betrays the messianic secret [88] with a kiss and proclaims herself as the Light, the burning torch, the candle of faith that is central to Christian worship. [89-91] Patriarchal language and some revisionist scholarship veil this. People who stubbornly believe there is only one male Jesus will resist this assertion. This article however, stands in opposition to that view and resists revisionist attempts to separate Mary Magdalene from the sinner woman of Luke 7. Rather this article says. Let the Forgiven Woman sin no more and come in Jesus' name. Let her light our path, our churches, and our hearts. Let her kiss Jesus the Father and Jesus the Son of the Father and his beloved Lady ${ }^{3}$ on the cheek and betray the messianic secret to the authorities. Let her go and tell the disciples. "I have seen the Lord."[76]

Seeing and believing in a female Jesus, we can see Jesus in the wilderness where she was tempted by Satan. [92] We can then see her saying to Simon called the rock, "get behind me Satan you are a stumbling block." [93] And then we can see her coming out of the wilderness leaning on her beloved. [75] We can see her bridegroom as the heart and soul of the Song of Solomon, to whom she sings, "My vineyard, my very own, is for myself...O you who dwell in the gardens, my companions are listening for your voice; let me hear it. Make haste, my beloved....[94] As the veil lifts, we may think our eyes are deceiving us because the truth reveals Jesus as the bodily incarnation of the three person Triune God, each living in love and thanksgiving for the other and all creation. [61]

As this article previously mentions, there were two Jesus' presented to Pilate. [50] Jesus called the Christ and Jesus Barabbas, the Son of the Father. Of course all through the Gospels there is a disciple that Jesus called the Twin. And at the resurrection this Twin says "Unless I see the nail marks in his hands and put my finger where the nails were, and put my hand into his side, I will not believe it."[95] The resurrection is not just about forgiveness. It is about the

\footnotetext{
${ }^{3}$ The name Martha means Mistress, Lady of the House. [1]
}

unification of the body. It is about the peace and reconciliation that comes with forgiveness and a faith that demands reconciliation. [96] Jurgen Moltmann [62] aptly says. "The church [the body of Jesus] is holy in its unity and in all its members, not in itself but in Christ." As Paul [97-98] says, we are all sons [children] of God. In Christ we are one. We are neither Jew nor Gentile, nor male, nor female, slave or free. So some may argue God has no gender or body and lives high above the world in the clouds, rather than in a cloud of faithful witnesses who clearly see Jesus appearing to Simon, the elder, Mary chose as her Lord-fulfilling scripture. [8,99-100]

\section{Concluding Thoughts}

Paying close attention to the Gospel with the intent of reversing the Fall and ending the exile and the curse of enmity between Eve and the Serpent, [101] it is evident the crucifixion, resurrection and ascension must reconcile this Serpent and welcome this Serpent as a gift of God, fully forgiven. This is imperative. Unless we can see the Serpent and every creature in the garden as God's gift to us, we will continue in our sins.

\subsection{Restorative Justice is Relational}

Faith in each other and faith in God's promise to rejoice with us in this reconciliation is what will bring opposing sides together within the church and restore the fourfold harmony of the garden of Eden. [102] It is what puts a song in Mary's mouth [103] and causes God and every creature to sing and rejoice. [104] It takes patience and it takes faithful listening even during times when we are so sure God has forsaken us and has stopped answering our prayers because all we hear in the silence is self-reproach and all we see in the darkness is the light from exploding bombs and clashing swords. It takes time and space to restore broken relationships. Giving each other the space and time to think things through is important. All sides need to see things from the other's position. Restorative justice is relational. It restores the broken trust and blesses everyone involved in the fallen relationship. It blesses the whistle blower, the one betraying the sanctity of silence, the rich and mighty one cursed for shrewd resource management, the one made the scapegoat and the one outcast as leprous or having a freckled or blackened skin colour. With time, patience, perseverance, love and hospitality, strangers and enemies will become friends and lovers who feel compelled and committed to being in that elect number who are dressed as family and friends honoring the bride and her bridegroom in the Kingdom of God - the garden of all gardens. [40,105]

This article concludes. Mary did not marry Jesus the Teacher whom she anointed as the Christ, thinking as many Christians have down through the ages that the Teacher was her Lord and her Bridegroom. The risen Jesus person greeting Mary in the garden overlooking the tombs is not 
Mary's Lord or her Bridegroom. He is the Son of the Father. $\mathrm{He}$ is the Teacher, the one who says to Mary, "Noli me tangere, do not touch me, for I have not ascended to the Father. [106] So truly this means Simon is Mary's Lord and her Bridegroom? For as John [107] writes, "He who has the bride is the bridegroom." Furthermore, Mary is the bride of whom the prophets speak and the Roman Catholic Church honoured as the bride of Solomon's Song for centuries. [1,5] And, Simon, the one who was a stumbling block, entered Mary's heart and appeared to the Rabbouni, causing the disciples to say. "It is true! The Lord has risen and has appeared to Simon." [108]

To see three persons coming in the name of Jesus the Christ takes faith. It seems foolish. [109] It is what makes many people stumble and ask "Is Christ divided?"[110] Many people do as they did in ancient Corinth, find it hard to understand how Jesus and the Christ can be one if there are two reconciled to each other by a third. Yet scripture says Christ Jesus is our peace because by bringing two groups into one, the dividing wall was broken down so that in Himself, He might make the two into one new man, one new faithful family, thus establishing peace. [48]

As ambassadors of Christ, Christians are invited to share in this mission of reconciliation to renew our faith in each other and to extend this restorative mission to the whole creation. At the Sustainable Alternatives to Poverty and Eco-Justice (SAPREJ) conference (for which this article was originally written) many bitterly treated people who have known abuse, colonization, poverty and war will come forward. They may ask? How can we love and restore a world torn apart by lust and greed? How can we forgive people who have sinned? How can we forgive people who have doubted our integrity and have abused our gifts and resources? How can we forgive people whose silence has hurt and abused us? How can we forgive people who steal from their own household purses? How can we forgive people who kill? How can we forgive people who buy big fancy houses, pretty clothes and vacations while our children go hungry? How can we forgive people who have abused us and our beloved people and have stolen all our hopes and dreams for a sustainable future? Where is justice? And like the one Jesus called the Twin they may say, unless we see the nail marks and experience this everlasting bond of love and forgiveness for ourselves, we will not believe. We will remain stinking and asleep in the tomb, like Lazarus. [111] We will remain 4 days or 40 days or 40 years asleep near death. Unless we hear Jesus call us and include us at the banquet table and treat us equitably as a loving person in this mission, we cannot believe.

This article says stop doubting. Believe. The Triune God is with us. God is Love because God is Triune. [61] Everyone who loves has seen God and is born of God [58] and the one and the many who have been forgiven much, love much. [60] We have been called to this banquet table. $\mathrm{We}$ are regarded as a loving person in this SAPREJ mission. We can listen and learn more about God, each other and creation, lifting up the question "Who is this who also forgives sins?" as a healing balm.

\section{REFERENCES}

[1] Vogt Turner L. Mary Magdalene: Her image and relationship to Jesus (Master's project, Simon Fraser University, Burnaby, British Columbia, Canada 2011), pp25-26, 50-53,108-111, Online available from

http://summit.sfu.ca/system/files/iritems1/12048/etd6959_L VogtTurner.pdf

[2] Winkett, Lucy. "Go Tell! Thinking about Mary Magdalene." Feminist Theology: The Journal of the Britain \& Ireland School of Feminist Theology.29 (2002): 19. Academic Search Premier. EBSCO. Web. 13 Sept. 2010.

[3] Pope, Hugh. "St. Mary Magdalen." The Catholic Encyclopedia, Vol. 9. New York: Robert Appleton Company, 1910. Web 24 Mar. 2010.

http://www.newadvent.org/cathen/09761a.htm

[4] Schaberg, Jane, with Melanie Johnson-Debaufre. Mary Magdalene Understood. Rev. ed. of The resurrection of Mary Magdalene. New York: Continuum International Publishing Group Inc, 2006, p59.

[5] Starbird, Margaret. The Woman with the Alabaster Jar: Mary Magdalen and the Holy Grail. Santa Fe: Bear \& Company, 1993, pp 28-29.

[6] Brown, Dan. The Da Vinci Code: Now a Major Motion Picture. London: Corgi Books, 2004.

[7] John 20:16 New Revised Standard Version

[8] John 20: 13 NRSV

[9] Mark 15:21 NRSV

[10] Romans 16:13 NRSV

[11] 2 John 1:1 New International Version, NRSV

[12] Disney, W. Disney's Little Mermaid. Walt Disney Pictures [DVD], 1989.

[13] Disney, Pixar. Brave. Walt Disney Pictures [DVD], 2012.

[14] Tatum, W. Barnes. Jesus at the Movies: A Guide to the First Hundred Years. Rev. and Expanded ed. Santa Rosa: Polebridge Press, 2004.

[15] Lloyd, David F. "Mary, Mary? Quite the Contrary! " Vision Insights and New Horizons spring (2005): n.pag. Web. 10 June 2010. http://www.vision.org/visionmedia/article.aspx?i $\mathrm{d}=1119 \&$ terms $=$ Mary + Mary + quite + contrary

[16] Swidler, Leonard, Jesus was a Feminist. Lanham, MD: Sheed \& Ward, 2007. N. Pag. Kindle file.

[17] Haskins, Susan. Mary Magdalen: Myth and Metaphor. San Diego: Harcourt Brace \& Company, 1993, p 392.

[18] Moltmann-Wendel, Elisabeth. The Women around Jesus: Reflections on Authentic Personhood, London: SCM Press Ltd.1982. 
[19] Barclay, William. The Daily Bible Series, revised edition: the Gospel of John Vol.2. Philadelphia: Westminster Press, 1975, p265.

[20] Buttrick, George Arthur. "Pharisees." The Interpreter's Dictionary of the Bible, Vol. 3. New York: Abingdon; 1962, pp 776-777.

[21] Luke 7: 36-50 NRSV

[22] Genesis 3:8 NRSV

[23] Genesis 3: 14-15 NRSV

[24] Oduyoye, Mercy. Who Will Roll the Stone Away? . Geneva: WCC Publications, 1990, p.39.

[25] Barclay, William. The Daily Bible Series, revised edition: the Gospel of Luke2. Philadelphia: Westminster Press, 1975, p95.

[26] Matthew 15:2-9 NRSV

[27] Mark 7: 1-3 NRSV

[28] John 15: 1-2 NIV

[29] Psalm 128:3 NIV

[30] 2 Corinthians 2:7 NIV

[31] 2 Corinthians 7:2 NIV

[32] Matthew 6: 9-12 NIV

[33] Luke 10:40 NIV

[34] John 11:5 NIV

[35] Owens Priscilla J. "Will your anchor hold in the storms of life?" 1829-1907. [cited 2015 July 13], Online available from: http://www.hymnary.org/hymn/CH4/737

[36] Luke 7:50 NRSV

[37] Luke 8:2 NRSV

[38] Mark 10:51 New American Standard Bible

[39] Luke 14: 15-24 NRSV

[40] Matthew 22: 1-14 NRSV

[41] 1 Peter 2:22 NRSV

[42] Papaderos, Alexandros K. "Aspects of Orthodox Social Ethics." In Trilogy on Social Ethics: Orthodox-Catholic-P rotestant, coauthors: Ingeborg G. Gabriel, Ulrich H. J. Kortner, Alexandros K. Papaderos, 21-132. Philadelphia: Ecumenical Press, 2012, p37.

[43] Luke 18:18-19 NRSV

[44] Matthew 19:17 NRSV

[45] Ouaknin, Marc-Alain. Symbols of Judaism. New York: Assouline Publishing, 2000, p106.

[46] 1 Corinthians 12:12, 27 NIV

[47] Acts 18:28 NIV

[48] Ephesians 2: 16 NIV

[49] 2 Corinthians 5:18 NIV
[50] Matthew 27: 11-26 Revised Standard Version

[51] Buttrick, George Arthur. "Barabbas." The Interpreter's Dictionary of the Bible, Vol. 1. New York: Abingdon; 1962, p353.

[52] John 19:19 NIV

[53] Matthew 27:12 King James Version

[54] 1 Corinthians 13: 12-13 NIV

[55] 1 Corinthians 13:12-13 NIV;KJV

[56] Romans 3: 23 NIV

[57] 2 Corinthians 5: 21 NIV

[58] 1 John 4:7 NIV

[59] 1 John 3:9 NIV

[60] Luke 7: 47-49 NRSV

[61] Lazareth, William H. "The Triune God: The Supreme Source of Life: Thoughts inspired by Rublev's icon of the Trinity," Document TH4-4 Vancouver BC: World Council of Churches Sixth Assembly, 1983.

[62] Moltmann, Jurgen. The Church in the Power of the Spirt. New York: Harper \& Row, 1975, p353.

[63] 1 Corinthians 1:23 NIV

[64] Psalm 62:2 NRSV; International Standard Version

[65] Micah 4:8-13 NIV

[66] Exodus 22:2, 23:9, Hebews 13, 1-2 NRSV

[67] John 19:19 Holman Christian Standard Bible

[68] 2 Corinthians 5: 17-21NRSV

[69] John 20: 15-16 NRSV

[70] Isaiah 29:1-4a NRSV

[71] Lamentations 1:1NRSV

[72] Psalm 45 NRSV

[73] John 20:15 NRSV

[74] John 20: 16-18 NRSV

[75] Song of Solomon 8:5 NRSV

[76] John 20: $18 \mathrm{NRSV}$

[77] Luke 24: 50-52 NRSV

[78] Luke 10:41 NRSV

[79] John 11:27 NRSV

[80] John 11:28 NRSV

[81] John 12:1-8 NRSV

[82] John 18: 1-11 NRSV

[83] Luke 22: 47-53 NRSV

[84] Luke 22: 3 Contemporary English Version 
[85] John 13: $27 \mathrm{CEV}$

[86] Mark 14: 9 NRSV

[87] Matthew 26:13 NRSV

[88] Mark 8:30 NRSV

[89] John 8:11-12 KJV

[90] Luke 22:3 NRSV

[91] John 13:26-27 NIV

[92] Mark 1:13 NIV

[93] Matthew 16:23 NIV

[94] Song of Solomon 8: 12-14 NRSV

[95] John 20:25 NIV

[96] 2 Corinthians 5: 11-21

[97] Galatians 3:26 NASB

[98] Galatians 3:28 NRSV
[99] Luke 24:34 NRSV

[100] Luke 10:42 NRSV

[101] Genesis 3: 5 NRSV

[102] Zephaniah 3:14-17 NRSV

[103] Luke 1: 46 NRSV

[104] Psalm 40: 1-3 NRSV

[105] Song of Solomon 8 NRSV

[106] John 20:17 NRSV

[107] John 3:29 NRSV

[108] Luke 24:34 NIV

[109] 1 Corinthians 1:18 NIV

[110] 1 Corinthians 1:13 NIV

[111] John 12:17,39 KJV 